\title{
ПЕРВЫЙ ЕВРАЗИЙСКИЙ
}

\section{АНТИКОРРУПЦИОННЫЙ ФОРУМ \\ И СЕДЬМАЯ МЕЖДУНАРОДНАЯ ШКОЛА \\ МОЛОДЫХ УЧЕНЫХ-ЮРИСТОВ}

C.E. Нарышкин

\section{МЕЖДУНАРОДНОЕ СООБЩЕСТВО В БОРЬБЕ С КОРРУПЦИЕЙ*}

\begin{abstract}
Аннотация. В статье рассматривается коррупщия в качестве одного из вызовов государственному и общественному развитию, а также освещаются различные аспекты противодействия данному явлению. Особое внимание уделяется совершенствованию законодательства в сфере противодействия коррупиии и усилению контроля за правоприменением в данной области. Подчеркивается роль в этом законодательной власти, использующей механизмы парламентского контроля и взаимодействия с исполнительной властью. Обращается внимание на необходимость международного сотрудничества в сфере борьбы с коррупиией, а также евразийской интеграции.
\end{abstract}

Ключевые слова: противодействие коррупиии, совершенствование законодательства, парламентская деятельность, правоприменение, международное сотрудничество.

$\mathrm{T}$ Такое явление как коррупция представляет собой один из серьезнейших вызовов человеческому развитию. Это проявляется в том, что коррупция не только подвергает риску суверенитет и безопасность государства: она подрывает сами устои человеческой цивилизации, нарушает нормальное развитие всех сфер жизни людей, снижает их нравственность и материальное благосостояние, а также усугубляет один из самых опасных как для нормальной человеческой жизни, так и для ведения бизнеса кризисов - кризис доверия. Общество, не разъединенное взаимной подозрительностью, способно много эффективней находить ответы на общие вызовы, и вполне возможно, что борьба за нравственность и избавление от правового нигилизма - едва ли не самая главная линия в борьбе с коррупцией.

Чтобы коррупционный проступок был признан противоправным, достаточно внести изменения в действующее законодательство, но чтобы он повсеместно осуждался и признавался в обществе глубоко аморальным, нужно сделать много больше. Во-первых, хотелось бы поставить перед участниками нынешней конференции вопрос о мерах, необходимых для дости-

* В основе статьи - доклад, представленный автором на Первом Евразийском антикоррупционном форуме и Седьмой Международной школе молодых ученых-юристов. Обзор работы Форума и Школы представлен ниже. жения указанной цели. Во-вторых, необходимо подчеркнуть, что общество, безусловно, должно иметь возможность защищаться от такого зла как коррупция и действенными правовыми инструментами.

В нашей стране уже немало сделано для этого. Существует национальный план противодействия коррупции, который не так давно был актуализирован в расчете на два ближайших года, при Президенте РФ действует Совет по противодействию коррупции. Была ратифицирована Конвенция Организации Объединенных Наций против коррупции и Конвенция Совета Европы об уголовной ответственности за коррупцию, а также ряд других международно-правовых актов. В Российской Федерации последовательно выстраивается комплексная законодательная база, отвечающая как международным стандартам, так и отечественным реалиям. Речь идет не только о базовом Федеральном законе «О противодействии коррупции», который был принят в декабре 2008 г., но и об уже прошедшей серьезной переработке норм административного, уголовного, финансового, гражданского, трудового законодательства и некоторых других отраслей.

Ряд законодательных инициатив, направленных на противодействие коррупции, в данный момент находятся в законопроектном портфеле Государственной Думы. Одна из принципиальных задач - свести к минимуму избыточные контакты с чиновниками со 
стороны граждан и юридических лиц при получении стандартных государственных и муниципальных услуг. Для этого должны не только внедряться информационные технологии, но и меняться сами законы: так, уже принят в первом чтении внесенный Правительством РФ законопроект, стимулирующий переход к предоставлению муниципальных и государственных услуг по принципу одного окна. Предстоит внести изменения в более чем два десятка законов, регулирующих отношения в таких сферах как образование и наука, здравоохранение, социальная защита населения, занятость и предпринимательство. В Государственной Думе идет работа и над законодательными инициативами, предусматривающими контроль за соответствием расходов и доходов государственных и муниципальных служащих, а также иных лиц, работающих в государственном секторе экономики.

Представляется, что в сфере противодействия коррупции не следует ограничиваться лишь совершенствованием законодательства: необходимо предпринимать и другие шаги. В первую очередь, следует усилить контроль за применением законов, поскольку правоприменение пока остается одним из слабых мест в российской антикоррупционной системе. В нынешних условиях будет возрастать роль и парламентского контроля за деятельностью органов исполнительной власти. В арсенале парламента есть такие мощные инструменты, как парламентские расследования, депутатские и парламентские запросы, заслушивание ежегодных отчетов Правительства и отдельных министров в рамках правительственных часов. Это серьезные возможности для реального влияния и на качество работы исполнительной власти, которые необходимо активно использовать. В настоящее время прорабатываются меры усилению таких полномочий.

Коррупция, конечно же, не является исключительно российской проблемой: она не признает государственных границ, а причины и условия, ее порождающие, во многом схожи, и присутствуют практически во всех странах. Поэтому меры, предпринимаемые на национальном уровне должны сочетаться с консолидированными действиями в международном масштабе. Прежде всего, необходимо предпринимать шаги в борьбе с легализацией средств, имеющих криминальное происхождение, поскольку только таким образом можно воспрепятствовать свободному перемещению преступных капиталов из одной страны в другую.

Что касается непосредственно евразийского региона, то здесь на очереди стоит вопрос о формировании единого пространства борьбы с преступностью, в том числе с коррупцией. В перспективе же необходимо строить общее правовое пространство евразийских государств. Представляется, что большая роль в развитии регионального антикоррупционного сотрудничества будет и должна принадлежать парламентариям: прямые контакты законодателей и их взаимодействие в евразийских межпарламентских институтах позволят не только обобщать накопленный опыт, но и согласованно двигаться дальше. В этой связи своевременной является организация Первого евразийского антикоррупционного форума, с инициативой проведения которого выступил Институт законодательства и сравнительного правоведения при Правительстве РФ, который выполняет, в том числе и функцию междисциплинарного, научного и учебно-методического центра по обеспечению противодействия коррупции.

В завершение хотелось бы отметить, что партнерам по евразийской интеграции необходимы общие, скоординированные и синхронизированные планы действий по многим направлениям. В том числе это «дорожные карты» в области экономики, в социальной сфере, в политике и в гуманитарной области, а также общая «дорожная карта» по вопросам противодействия коррупции. В связи с этим Первый евразийский антикоррупционный форум представляет собой хорошую возможность обсудить различные аспекты формирования этой «дорожной карты» нашей общей безопасности и противодействия коррупции.

\section{Библиографический список:}

1. Конвенция об уголовной ответственности за коррупцию. Заключена в г. Страсбурге 27 января 1999 г. // Бюллетень международных договоров. 2009. № 9. С. 15-29.

2. Конвенция Организации Объединенных Наций против коррупции. Принята в г. Нью-Йорке 31 октября 2003 г. Резолюцией 58/4 на 51-ом пленарном заседании 58-ой сессии Генеральной Ассамблеи ООН // Бюллетень международных договоров. 2006. № 10. С. 7-54.

3. Федеральный закон от 25 декабря 2008 г. № 273-ФЗ «О противодействии коррупции» // С3 РФ. 2008. № 52 (ч. 1). Ст. 6228.

4. Указ Президента РФ от 13 марта 2012 г. № 297 «О Национальном плане противодействия коррупции на 20122013 годы и внесении изменений в некоторые акты Президента РФ по вопросам противодействия коррупции» // СЗ РФ. 2012. № 12. Ст. 1391. 